Available online at http://jddtonline.info

RESEARCHARTICLE

\title{
FORMULATION AND EVALUATION OF BILAYER FLOATING TABLET OF CARVEDILOL PHOSPHATE
}

\author{
Chaudhari Shilpa*, Bawaskar Manish, Shirsat Ajinath \\ Department of Pharmaceutics, Marathwada Mitra Mandal's, College of Pharmacy, Thergaon, Pune-33, Maharashtra, India \\ Corresponding Author's Phone: +91-9881994293,E-mail:shilpapchaudhari78@yahoo.com
}

Received 05 August 2012; Review Completed 09 Sep 2012; Accepted 13 Sep 2012, Available online 15 Sep 2012

\begin{abstract}
Gastroretentive dosage forms (GRDF) enable prolonged and continuous input of the drug to the upper parts of the gastrointestinal tract and improve the bioavailability of medications those are characterized by a narrow absorption window. The aim of this study was first to develop and physico-chemically characterize an optimal single unit bilayer floating tablet for Carvedilol phosphate (CP) prepared by direct compression technology secondly use Ocimum basilicum mucilage (OBM) as a gelling, swelling and sustaining polymer in combination with HPMC and compared their drug release profile with marketed sustained release formulation for once-a-day administration of Carvedilol. Effect of OBM and its concentration on tablet properties such as hardness, friability, floating characteristics, swelling properties, tablet erosion and release patterns were evaluated. The release rate and floating characteristics could effectively be modified by varying "matrix forming swelling polymer, gas-generating agent" ratio. Drug release in optimized formulation was approximately $93.80 \%$ in $24 \mathrm{~h}$ in vitro and floating lag time around $5 \mathrm{~min}$. The results showed floating tablets are a feasible approach for the sustained release (SR) preparation of CP.

Keywords: Gastroretentive, Bilayer floating, Carvedilol phosphate, HPMC, Ocimum basilicum mucilage.
\end{abstract}

\section{INTRODUCTION:}

Carvedilol (CV) is a non-cardioselective alpha ${ }_{1}$ - beta adrenergic blocking agent with no intrinsic sympathomimetic activity and weak membrane-stabilising activity. The alpha ${ }_{1}$-adrenergic blocking activity of CV causes vasodilation and reduces peripheral vascular resistance. At higher doses calcium channel blocking activity also observed. CV is most effective in management of hypertension, in angina pectoris, heart failure, and left ventricular dysfunction with myocardial infarction. CV has a terminal half-life of 7-10 hr, but most of the drug is eliminated with a half-life of about $2 \mathrm{hr}$, and the recommended oral dose for adult is two times a day. $\mathrm{CV}$ has advantage over traditional $\beta$-blockers with respect to hemodynamic and metabolic effects. Such results indicate its safe and effective therapeutic application particularly in patients with complicated Cardiovascular Diseases (CVDs), even in paediatric and geriatric patients. ${ }^{1}$ $\mathrm{CV}$ has narrow absorption window i.e. upper part of gastrointestinal tract (GIT).Therefore a good candidate for gastroretentive dosage form. ${ }^{2}$

It is widely known that gastric residence time (GRT) is one of the important factors affecting the drug bioavailability of pharmaceutical dosage forms. ${ }^{3}$ Variable and short gastric emptying time can result in incomplete drug release from the dosage form (DF) above the absorption zone (stomach or upper part of small intestine), leading to a diminished efficacy of the administered dose. ${ }^{4}$ Though oral SR-DF have been developed due to their important therapeutic advantages, this approach has not been suitable for a variety of important drugs, characterized by a narrow absorption window in the upper part of the GIT. ${ }^{5}$ After only a short period of less than $6 \mathrm{~h}$, the SR-DF has already left the upper gastrointestinal tract and the drug is released in nonabsorbing distal segments of the GIT. ${ }^{6}$ This results in a short absorption phase that is often accompanied by lesser bioavailability. Also SR-DF has limited advantage for locally active drugs in the stomach; those are unstable in the intestinal or colonic environment, and exhibit low solubility at high $\mathrm{pH}$ values.

These limits promoted the development of Gastro Retentive Dosage forms.

Gastro Retentive Dosage forms that were designed in large part based on the following approaches:

- Low density DF shows buoyancy above gastric fluid. ${ }^{8}$

- High density DF retained in the bottom i.e. antrum of the stomach.

- Bioadhesion to the stomach mucosa. ${ }^{10}$

- Slowed motility of the GIT by concomitant administration of drugs or pharmaceutical excipients or food agents like fatty acids. ${ }^{11}$

- Expansion by swelling or unfolding to a large size which does not allow the DF to pass through the pyloric sphincter. $^{12}$

In case of oral drug delivery systems compressed hydrophilic matrices are commonly used because of their good compatibility. Drug release from hydrophilic matrix tablets is controlled by formation of a hydrated viscous layer around the tablet which acts as a barrier to drug release by opposing penetration of water into tablet and also movement of dissolved solutes out of the matrix tablets. The overall drug release process is influenced by drug solubility, physical and mechanical properties of the gel barrier that forms around the tablet. The extent of matrix swelling, erosion, and diffusion of drug determines the kinetics as well as the mechanism of drug release. ${ }^{13}, 14$, 15 
Shilpa et al

Journal of Drug Delivery \& Therapeutics; 2012, 2(5), 9-19

OBM is studied for its rheology, binding properties and Disintegrant properties, but its use as a gelling, swelling and sustaining polymer is not yet studied therefore in this paper we have tried to use natural polymer i.e., OBM as a gelling, swelling and sustaining polymer in combination with HPMC and developed the sustaining formulation of $\mathrm{CP}$ by Gastro retentive technology to maintain the resultant buoyancy for duration of upto $22 \mathrm{~h}$. This formulation of the matrix dosage form with two distinct layers allows separate regulation of the floating capabilities and drug release kinetics.

\section{MATERIALS AND METHODS:}

\section{Materials:}

Carvedilol phosphate was gifted by Cipla Ltd., India. HPMC K100M and Microcrystalline cellulose (MCC) were obtained as gift samples from Colorcon Asia Pvt. Ltd., Mumbai. Magnesium stearate was gifted by Kopran Ltd., Khopoli. Sodium bicarbonate (Analytical grade) was purchased from Research lab fine chem. Industry. Basil seeds (Sabja, Ocimum basilicum L.) used in study were purchased from Ayurvedic medical store from local market at Mumbai, India. All other reagents were purchased from Merck Pvt. Ltd., India and were of analytical grade. All the studies were carried in distilled water.

\section{Authentification of Basil Seeds:}

Plant developed from the seeds purchased from local market and there after herbarium was made with plant and seeds sample. This sample was sent to the Botanical Survey of India, Pune. Authentification of sample was done by Scientist 'C' In-charge.

\section{Mucilage extraction from basil seeds:}

The extraction of gum from basil seeds was performed by modifying the method given in S.H. Hosseini-Parvar et al., $2010 .^{16}$ The basil seeds were soaked and swelled in distilled water at $68 \pm 1{ }^{\circ} \mathrm{C}$ and a water/seed ratio of 65:1. The mixture was stirred with a mechanical stirrer (Remi motor, Remi Elektrotechnik Ltd.) until the seeds were completely swelled (4 hrs agitation, $500 \mathrm{rpm}$ ). The swelled seeds were passed through a high speed homogenizer at 6000 rpm (Remi motor, Remi Elektrotechnik Ltd.) to separate the gum layer from the seed surface. Then the total mixture is squeezed manually by hand through (40\#) muslin cloth so that seeds get separated from gum and then gum was washed with acetone to remove any soluble impurities. The precipitated OBM separated, vacuum dried in vacuum oven (Lab Hosp, Mumbai; with vacuum pump of capacity 50Lt/min, vacuum 0.005 Torr, Atharva Vacuum Technologies Pvt. Ltd.) at $30-40{ }^{\circ} \mathrm{c}$, powdered and passed through sieve (80\#), then stored in tightly closed containers under dry and cool conditions.

\section{Spray drying of $O B M$ :}

A Microcontroller Operated Unit - LU - 222 Advanced Lab Spray Dryer with pre-HEPA filter (Labultima, Mumbai, India), equipped with a co-current (to hot air flow) - $0.7 \mathrm{~mm}$, fluid spray nozzle with Autojet Deblocking System having variable stroke interval controlled through microcontroller was used to dry the gum. Drying chamber consist of 6" Borosilicate glass with specific dimensions through which the gum solution was fed using peristaltic pump of capacity $1250 \mathrm{ml} / \mathrm{hr}$ with
$3 \mathrm{~mm}$ internal diameter tube and having variable speed control. Various parameters selected for optimised batch were: Inlet air temperature $\left(220^{\circ} \mathrm{c}\right)$, Outlet air temperature $\left(100{ }^{0} \mathrm{c}\right)$, Aspirator flow rate $\left(45 \mathrm{Nm}^{3} / \mathrm{hr}\right)$, Feed pump flow rate $(8 \mathrm{ml} / \mathrm{min})$, Atomisation rate of $2-3$ bars. Distilled water at room temperature was used for preparing gum solution, start-up and shut down operations.

\section{pH determination of $\mathrm{OBM}$ solution:}

$0.1 \%$ OBM solution was used to determine the $\mathrm{pH}$ with calibrated Digital pH meter, model - EQ-610 (EQUIP TRONICS). $100 \mathrm{ml}$ solution was used to measure $\mathrm{pH}$.

\section{Viscosity measurement of $\mathrm{OBM}$ :}

Viscosity measurements were carried out using Brookfield Viscometer [DV-II + Pro] in small sample adapter with spindle number 18 (Brookfield Engineering Labs. Inc.). Different concentrations of OBM were prepared by hydrating dried hydrocolloid powder in distilled water while stirring for $2 \mathrm{~h}$ using a mechanical stirrer. The dispersions were then left for sometime at $4{ }^{\circ} \mathrm{C}$ to ensure a complete hydration. For test, hydrated samples were loaded into the small sample adapter and allowed to equilibrate for $10 \mathrm{~min}$ at Room Temperature (RT) and were subjected to a programmed shear rate increasing from 0.396 to $132 \mathrm{~s}^{-1}$.

\section{Determination Water absorption capacity (WAC):}

WAC was determined by modifying the method described by Sciarini et al. (2009). ${ }^{17}$ The gum $(0.02 \mathrm{~g})$ was completely wetted with distilled water in a test tube. Then test tube was centrifuged at $10000 \mathrm{rpm}$ for $30 \mathrm{~min}$, the supernatant discarded, and the swollen sample weighed. The WAC was calculated as:

$$
\mathrm{WAC}=(\mathrm{ssw}-\mathrm{sw}) / \mathrm{sw}
$$

Where,

ssw $=$ the swollen sample weight and

$\mathrm{sW}=$ is initial sample weight taken (before wetting).

\section{Effect of pH on WAC:}

Same study was repeated by using $0.1 \mathrm{~N} \mathrm{HCl}$ and $0.1 \mathrm{~N}$ $\mathrm{NaOH}$ instead of distilled water.

\section{Morphological analysis using Scanning Electron Microscope (SEM):}

The outer macroscopic structures of the samples were investigated by scanning electron microscope (Jeol JSM 6360 A, Tokyo, Japan). The samples were fixed on a brass stub using double-sided adhesive tape and were made electrically conductive by coating of about $10{ }^{0} \mathrm{~A}$ with platinum in Argon atmosphere using Hitachi Ion Sputter (E- 1010) for $5 \mathrm{~min}$. The SEM images were analyzed with an image analysis system for particle size and morphological analysis.

\section{Drug - excipient compatibility study:}

The interaction was studied for prediction of stability and compatibility between drug and polymer which was analyzed by using IR spectroscopy and DSC study. Physical mixtures were prepared by triturating drug and excipients in mortar and kept in stability chamber at $45{ }^{\circ} \mathrm{C}$ $\pm 2{ }^{0} \mathrm{C} / 75 \% \mathrm{RH} \pm 5 \% \mathrm{RH}$ for one week. After one week 
Shilpa et al

Journal of Drug Delivery \& Therapeutics; 2012, 2(5), 9-19

samples were evaluated for interaction study by chemical analysis using IR and DSC studies.

Preparation of single unit bilayer and floating matrix tablet:
CP bilayer floating tablets were prepared by direct compression technology. Bilayer tablet contains two layers i.e. floating layer and sustained release layer.

Table 1: Formulation Table

\begin{tabular}{|c|c|c|c|c|c|c|c|c|c|c|c|c|c|c|c|c|}
\hline \multicolumn{17}{|c|}{ Composition of Floating Layer } \\
\hline $\begin{array}{l}\text { FORMULATION } \\
\text { COMPOSITION/ } \\
\text { Code }\end{array}$ & $\mathrm{F} 1$ & $\mathrm{~F} 2$ & F3 & $\mathrm{F} 4$ & F5 & F6 & F7 & F8 & F9 & F10 & F11 & $\mathrm{F} 12$ & F13 & F14 & F15 & F16 \\
\hline HPMC K100M & 60 & 30 & 60 & 30 & 40 & 50 & 60 & 60 & 30 & 40 & 40 & 50 & 40 & 50 & 50 & 30 \\
\hline $\begin{array}{c}\text { SODIUM } \\
\text { BICARBONATE }\end{array}$ & 30 & 50 & 20 & 40 & 40 & 30 & 50 & 40 & 30 & 30 & 20 & 50 & 50 & 20 & 40 & 20 \\
\hline $\begin{array}{l}\text { MAGNESIUM } \\
\text { STEARATE }\end{array}$ & 0.15 & 0.15 & 0.15 & 0.15 & 0.15 & 0.15 & 0.15 & 0.15 & 0.15 & 0.15 & 0.15 & 0.15 & 0.15 & 0.15 & 0.15 & 0.15 \\
\hline $\begin{array}{c}\text { OCIMUM } \\
\text { BASILICUM } \\
\text { MUCILAGE }\end{array}$ & $\begin{array}{l}59 . \\
85\end{array}$ & $\begin{array}{l}69 . \\
85\end{array}$ & $\begin{array}{l}69 . \\
85\end{array}$ & $\begin{array}{l}79 . \\
85\end{array}$ & $\begin{array}{l}69 . \\
85\end{array}$ & $\begin{array}{l}69 . \\
85\end{array}$ & $\begin{array}{l}39 . \\
85\end{array}$ & $\begin{array}{l}49 . \\
85\end{array}$ & $\begin{array}{l}89 . \\
85\end{array}$ & $\begin{array}{l}79 . \\
85\end{array}$ & $\begin{array}{l}89 . \\
85\end{array}$ & $\begin{array}{l}49 . \\
85\end{array}$ & $\begin{array}{l}59 . \\
85\end{array}$ & $\begin{array}{l}79 . \\
85\end{array}$ & $\begin{array}{l}59 . \\
85\end{array}$ & $\begin{array}{c}99.8 \\
5\end{array}$ \\
\hline \multicolumn{17}{|c|}{ Composition of Sustain release layer } \\
\hline HPMC K100M & 10 & 40 & 20 & 40 & 30 & 10 & 30 & 10 & 40 & 20 & 10 & 20 & 40 & 20 & 30 & 30 \\
\hline $\begin{array}{c}\text { OCIMUM } \\
\text { BASILICUM } \\
\text { MUCILAGE }\end{array}$ & 40 & 30 & 10 & 20 & 10 & 20 & 40 & 30 & 40 & 20 & 10 & 30 & 10 & 40 & 20 & 30 \\
\hline $\begin{array}{l}\text { CARVEDILOL } \\
\text { PHOSPHATE }\end{array}$ & 40 & 40 & 40 & 40 & 40 & 40 & 40 & 40 & 40 & 40 & 40 & 40 & 40 & 40 & 40 & 40 \\
\hline $\begin{array}{l}\text { MAGNESIUM } \\
\text { STEARATE }\end{array}$ & $\begin{array}{c}0.1 \\
5\end{array}$ & $\begin{array}{c}0.1 \\
5\end{array}$ & $\begin{array}{c}0.1 \\
5\end{array}$ & $\begin{array}{c}0.1 \\
5\end{array}$ & $\begin{array}{c}0.1 \\
5\end{array}$ & $\begin{array}{c}0.1 \\
5\end{array}$ & $\begin{array}{c}0.1 \\
5\end{array}$ & $\begin{array}{c}0.1 \\
5\end{array}$ & $\begin{array}{c}0.1 \\
5\end{array}$ & $\begin{array}{c}0.1 \\
5\end{array}$ & $\begin{array}{c}0.1 \\
5\end{array}$ & $\begin{array}{c}0.1 \\
5\end{array}$ & $\begin{array}{c}0.1 \\
5\end{array}$ & $\begin{array}{c}0.1 \\
5\end{array}$ & $\begin{array}{c}0.1 \\
5\end{array}$ & 0.15 \\
\hline $\begin{array}{c}\text { MICROCRYSTA } \\
\text { LLINE } \\
\text { CELLULOSE }\end{array}$ & $\begin{array}{l}59 . \\
85\end{array}$ & $\begin{array}{l}39 . \\
85\end{array}$ & $\begin{array}{l}79 . \\
85\end{array}$ & $\begin{array}{l}49 . \\
85\end{array}$ & $\begin{array}{l}69 . \\
85\end{array}$ & $\begin{array}{l}79 . \\
85\end{array}$ & $\begin{array}{l}39 . \\
85\end{array}$ & $\begin{array}{l}69 . \\
85\end{array}$ & $\begin{array}{l}29 . \\
85\end{array}$ & $\begin{array}{l}69 . \\
85\end{array}$ & $\begin{array}{l}89 . \\
85\end{array}$ & $\begin{array}{l}59 . \\
85\end{array}$ & $\begin{array}{l}59 . \\
85\end{array}$ & $\begin{array}{l}59 . \\
85\end{array}$ & $\begin{array}{l}59 . \\
85\end{array}$ & $\begin{array}{c}39.8 \\
5^{1}\end{array}$ \\
\hline
\end{tabular}

All quantities mentioned are in $\mathbf{m g}$

As per given in formulation table 1, Floating layer contains varied proportion of hydrophilic polymers (HPMC K100M and OBM), gas generating agent (sodium bicarbonate) and in sustained release layer amount of CP was kept constant at 40mg while the amount of other excipients i.e. HPMC K100M, OBM and MCC was varied. Magnesium stearate was used as lubricant in both layers. All ingredients were passed through sieve (40\#) and mixed uniformly for 10-15 min in polythene bag. Weighed quantity of SR layer equivalent to $150 \mathrm{mg}$ was compressed at pressure of 0.5 ton for 30 seconds. Weighed quantity of floating layer equivalent to $150 \mathrm{mg}$ was added on the slightly compressed SR layer and both the layers were compressed into the tablet using a manual $\mathrm{KBr}$ hydraulic press (PCi, India) with a die of $13.06 \mathrm{~mm}$ diameter flat punches at pressure of 3.5 tons for 30 seconds.

\section{Evaluation of powder blends (Precompression Parameters):}

Bulk density, tapped density, angle of repose, compressibility index (Carr's Index), Hausner's Ratio were evaluated as per standard procedures.

\section{Post Compression Parameters:}

\section{Tablet Hardness:}

The hardness of tablet of each formulation was measured by Monsanto hardness tester. The hardness was measured in terms of $\mathrm{kg} / \mathrm{cm}^{2}$.

\section{Friability of the tablets:}

For friability study twenty tablets of the formulation were weighed. Roche type friabilator was used for this study. The tablets were rotated at $25 \mathrm{rpm}$ for $4 \mathrm{~min}$, and then dedusted it and reweighed. The percentage friability was calculated using the equation:

$$
\mathrm{F} \%=\mathrm{W} 1-\mathrm{W} 2 / \mathrm{W} 1 \times 100
$$

Where F\% is the percentage weight loss, and

$\mathrm{W} 1$ and W2 are the initial and final tablets weights, respectively. 
The mucoadhesive forces of the bilayer tablets were determined by means of modified analytical two pan balance. The pieces of stomach (Fundus) tissue of goat were taken in saline solution to $37^{\circ} \mathrm{C}$ before use. At the time of testing a section of tissue was attached, keeping the mucosal side out, on to upper glass vial. Vial with a section of tissue was connected to the pan balance and the other vial was fixed on a lower side, height to adjustable pan. To the lower vial, a bilayer tablet was applied with the help of double-sided adhesive tape. The height of the vial was adjusted so that the tablet could adhere to the mucosal tissues of upper vial. Weights were added at a constant rate to the pan on the other side of the modified balance of the used device until the tablet gets detached from tissue. The bioadhesive force, expressed as the detachment stress in dyne $/ \mathrm{cm}^{2}$, was determined from the minimal weights required for the detachment using the following equation ${ }^{18}$ :

$$
\text { Detachment stress }\left(\text { dynes } / \mathrm{cm}^{2}\right)=\mathrm{mg} / \mathrm{A}
$$

Where,

$\mathrm{m}=$ the weight added to the balance in gram.

$\mathrm{g}=$ acceleration due to gravity taken as $980 \mathrm{~cm} / \mathrm{sec}^{2}$.

$\mathrm{A}=$ area of tissue exposed and is equal to $\Pi \mathrm{r}^{2}$

(r-the radius of the tablet attached to tissue).

\section{The floating lag time and the total floating time:}

Floating behaviour studies were performed on both the floating layer and bilayer floating tablet, carried out in a USP Dissolution Testing Apparatus II (Paddle type) at paddle speed $50 \mathrm{rpm}$ in $900 \mathrm{ml} 0.1 \mathrm{~N} \mathrm{HCl}$ at $37 \pm 0.2{ }^{\circ} \mathrm{C}$ for $24 \mathrm{hrs}$ to mimic in vivo conditions. For determining the optimized floating lag time and total floating time of the delivery system, various formulations prepared as per table 1 were studied. The time interval between the introduction of the tablet into the dissolution medium and its buoyancy to the top of dissolution medium was taken as floating lag time, the duration of system floatation and also the relative matrix integrity was observed visually.

\section{Swelling Characteristics:}

Swelling property of tablet was determined by placing it in the dissolution test apparatus, in $900 \mathrm{ml}$ of $0.1 \mathrm{~N} \mathrm{HCL}$ at $37 \pm 2{ }^{\circ} \mathrm{C}$. The weight and volume reached by the matrix tablets over time was determined by withdrawing the tablets periodically from dissolution medium. The tablets were weighed on an analytical balance after slight blotting with tissue paper to remove the excess test liquid. The volume of the tablets was obtained by measuring the thickness and diameter, considering a right circular cylinder form. The determined weight and volume were used to calculate the tablet density over the dissolution study. Swelling characteristics were expressed in terms of percentage water uptake (WU \%) according to the equation:

WU $\%=\mathrm{Wt}$. of swollen tablet - Initial wt. of tablet / Initial wt. of tablet $\times 100$

\section{determination:}

The magnitude and the direction of total force $F$ correspond to the vectorial sum of the buoyancy $\left(F_{\text {buoyancy }}\right)$ and gravity $\left(F_{\text {gravity }}\right)$ forces acting on the object.

$\mathrm{RW}$ or $\mathrm{F}=F_{\text {buoyancy }}-F_{\text {gravity }}=\mathrm{D}_{\mathrm{f}} \mathrm{gV}-\mathrm{D}_{\mathrm{s}} \mathrm{gV}=\left(\mathrm{D}_{\mathrm{f}}\right.$ $\left.-D_{\mathrm{s}}\right) \mathrm{gV}=\left(\mathrm{D}_{\mathrm{f}}-\mathrm{M} / \mathrm{V}\right) \mathrm{gV}$

Where,

$\mathrm{RW}$ or $\mathrm{F}=$ total vertical force

$\mathrm{D}_{\mathrm{f}}=$ fluid density

$\mathrm{D}_{\mathrm{s}}=$ object density

$M=$ object mass

$\mathrm{V}=$ volume

$\mathrm{g}=$ acceleration due to gravity

The total force $F$ acting vertically on an immersed object may be used to quantify the object floating or non-floating capabilities. A positive total force $F$ signifies that the object is able to float, whereas a negative $F$ means that the object sinks. The larger the total force $F$ value of the object, the more excellent its floating capability. ${ }^{6}$ The medium used was preheated $0.1 \mathrm{~N}$. $\mathrm{HCl}$ at $37 \pm 2{ }^{\circ} \mathrm{C}$.

\section{In-Vitro Drug release:}

Dissolution studies were performed in $900 \mathrm{ml}$ of $0.1 \mathrm{~N} \mathrm{HCl}$ (pH 1.1) using USP Dissolution Testing Apparatus II (Paddle type), at 50rpm and $37 \pm 0.5{ }^{\circ} \mathrm{C}$ (Tablet Dissolution Test Apparatus, Veego / VDA - 6D USP standards). The amount of drug released over time was determined by withdrawing samples at various determined time intervals for $24 \mathrm{hrs}$ and were replaced with fresh dissolution medium. The aliquots were filtered through Whatman filter paper Grade-1and concentration of drug was obtained by measuring the absorbance at $241 \mathrm{~nm}$, in UV-visible spectrophotometer (Shimadzu UV - 1800).

\section{RESULTS:}

\section{Authentification of Basil Seeds:}

The Samples of Ocimum basilicum seeds were authenticated by Botanical Survey of India, Pune with sample code No. BSI/ WC/ Tech. / 2012/ 624 and was found to be Ocimum basilicum L var. thyrsiflorum (L.) Benth. Family: Lamiaceae.

\section{Mucilage extraction from basil seeds:}

The yield of the mucilage was between $12-14 \%$ w/w on extraction from seeds. The yield was found to improve with the use of High speed homogenizer than by using simple stirrer or mortar and pestle (for separation of mucilage from seeds).

\section{Viscosity measurement of OBM:}

From viscosity study figure (1) it can be said that OBM system is shear thinning system. Because from graph it is clear that as shear rate increases the viscosity decreases. 


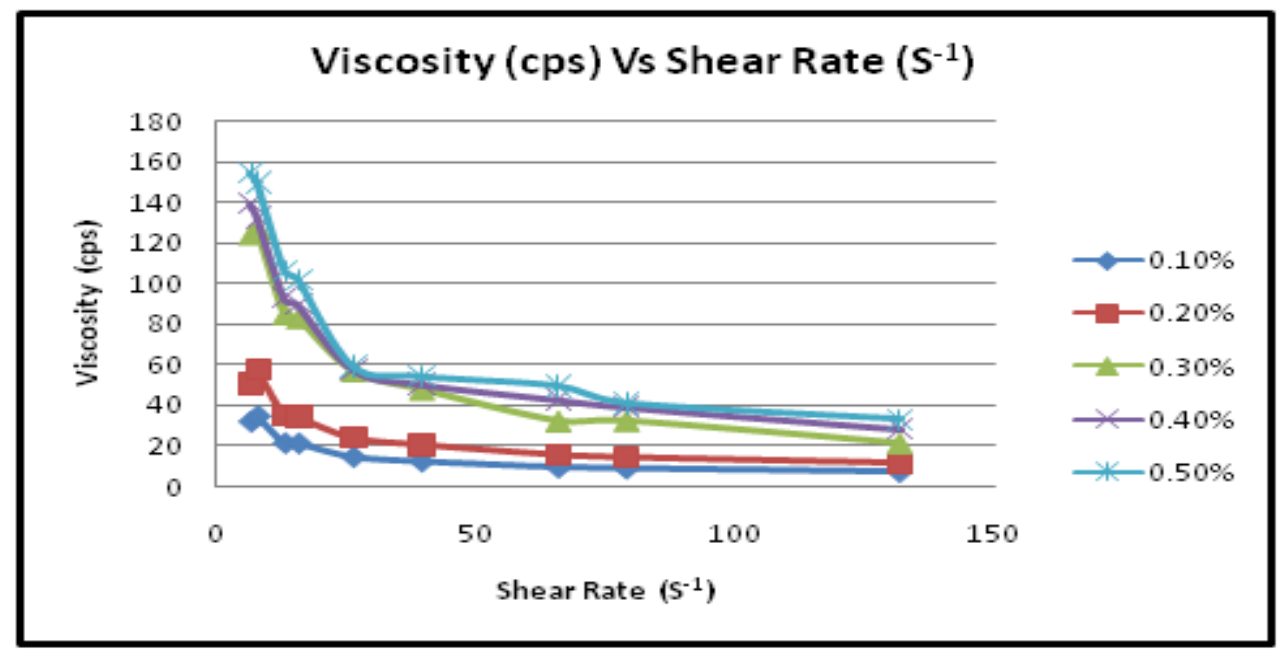

Figure 1 Graph of Viscosity (cps) Vs Shear Rate (S-1)

\section{Spray drying of OBM:}

For spray drying various parameters were selected by trial and error. Main parameters which affected the yield and nature of product were inlet temperature, feed pump rate, and atomization pressure.

Parameters for optimized batch were found to be:

a) Inlet temperature: $220{ }^{\circ} \mathrm{C}$

b) Outlet temperature: $100{ }^{\circ} \mathrm{C}$

c) Inlet high: $240{ }^{\circ} \mathrm{C}$

d) Outlet high: $180{ }^{\circ} \mathrm{C}$

e) Aspirator flow rate: $45 \mathrm{Nm} 3 / \mathrm{hr}$

f) Feed pump rate: $8 \mathrm{ml} / \mathrm{min}$

g) On - Deblocking on: $1 \mathrm{sec}$

h) On - Deblocking off: $10 \mathrm{sec}$

i) Atomization pressure: $2.5 \mathrm{Kg} / \mathrm{m} 2$

Spray drying improved the flow and compressional properties of the powder blend.

\section{Determination Water absorption capacity (WAC):}

Water absorption capacity was found to high 100.5.

\section{Effect of pH on WAC:}

The $\mathrm{pH}$ of mucilage solution was found to 7.24. WAC in $0.1 \mathrm{~N} . \mathrm{HCl}(\mathrm{pH} 1.1)$ and $0.1 \mathrm{~N} . \mathrm{NaOH}(\mathrm{pH} \mathrm{13})$ was found to be 95.6 and 97.6 respectively.

\section{Morphological analysis using Scanning Electron Microscope (SEM):}

Spray drying improved the morphological characteristics of particles with smaller particle size of around $4-5 \mu \mathrm{m}$, uniform spherical in shape having smooth surface. Based on the analysis of scanning electron microscopy the OBM dried in oven (figure 2) showed large particle size of around $100 \mu \mathrm{m}$ with rough surface, non-uniform shape. After spray drying the OBM powder SEM images showed particles with smaller particle size of around 4-5 $\mu \mathrm{m}$ was uniform in appearance, due to spherical particles flow property and matrix forming property improved, tablets were intact with less friability and sustained their floating efficiency for more than $20 \mathrm{hrs}$.

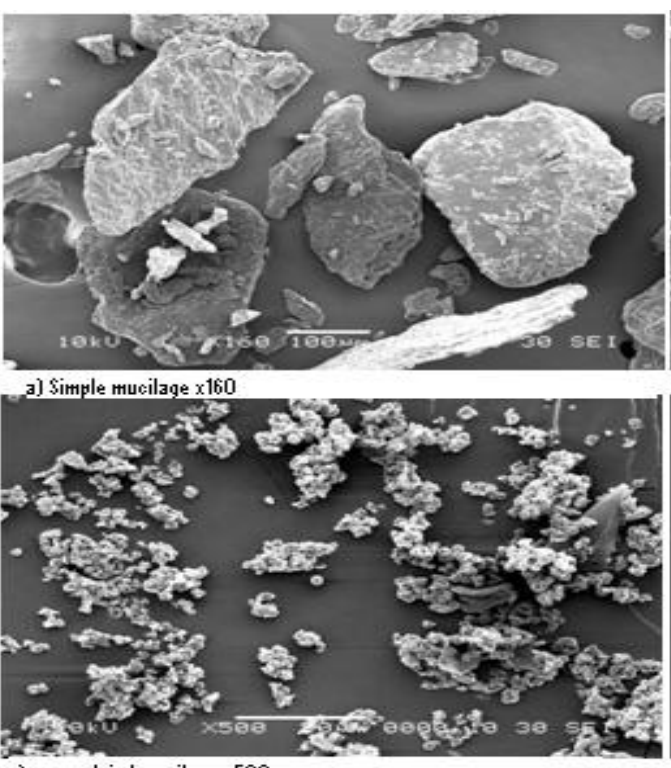

c) spray dried mucilage $x 500$

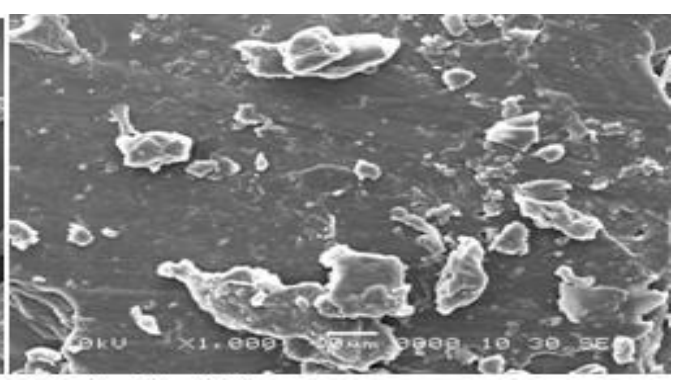

b) simple mucilage $x 1.000$

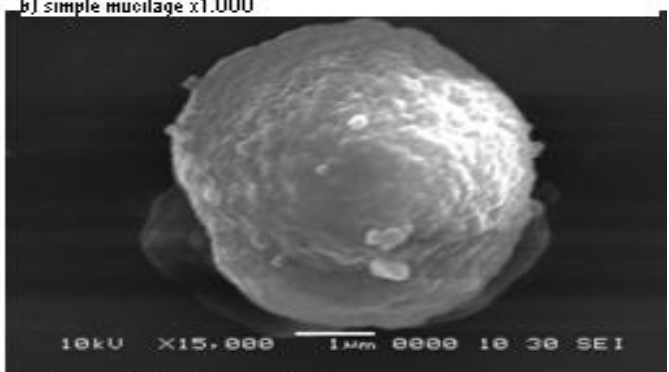

d) Spray dried mucilage $x 15.000$

Figure 2: SEM Image of OBM Simple and Spray dried 
Shilpa et al

Drug - excipient compatibility study:

Figure (3c) DSC spectra of Spray dried mucilage showed the broad endothermic peak at $124.8{ }^{0} \mathrm{C}$. Broad endothermic peak in DSC curve indicates the crystallization of the polymers as well as evaporation of water in the sample of polymer and decomposition of side chain. ${ }^{19,20}$

The endotherm obtained from the mixture figure (3b) showed characteristic peaks at $97.1^{\circ} \mathrm{C}$ and $160.5^{\circ} \mathrm{C}$, as that of present in the standard DSC spectra of pure drug sample Figure (3a).
Figure (4A) IR spectrum indicated characteristic peaks belonging to major functional groups such as principal peaks at wavenumbers 2924 and $3342 \mathrm{~cm}^{-1}$ shows presence of $-\mathrm{OH}$ and $-\mathrm{CH}$ stretching as mostly observed in polymers. An IR spectrum (figure 4B) shows that there was no drastic change in the peaks when compared with pure drug IR spectra. It clearly indicated that there was no interaction of drug with excipients.

\section{Precompression Parameters}

The precompression parameters were evaluated and were observed in the limit of good to passable flowability for most of the formulations as per IP specifications (Table 2).
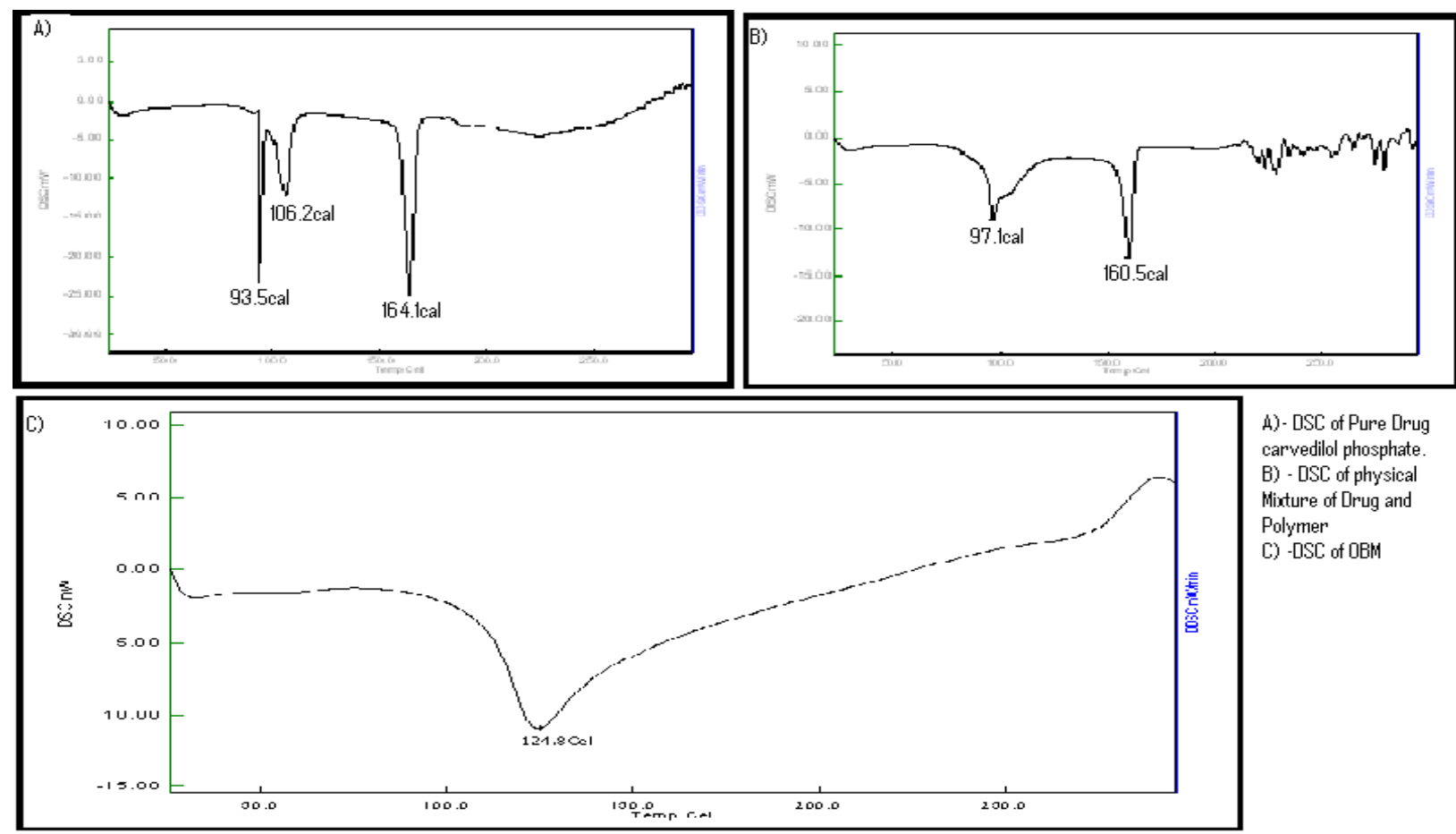

Figure 3: Differential Scanning Calorimetry
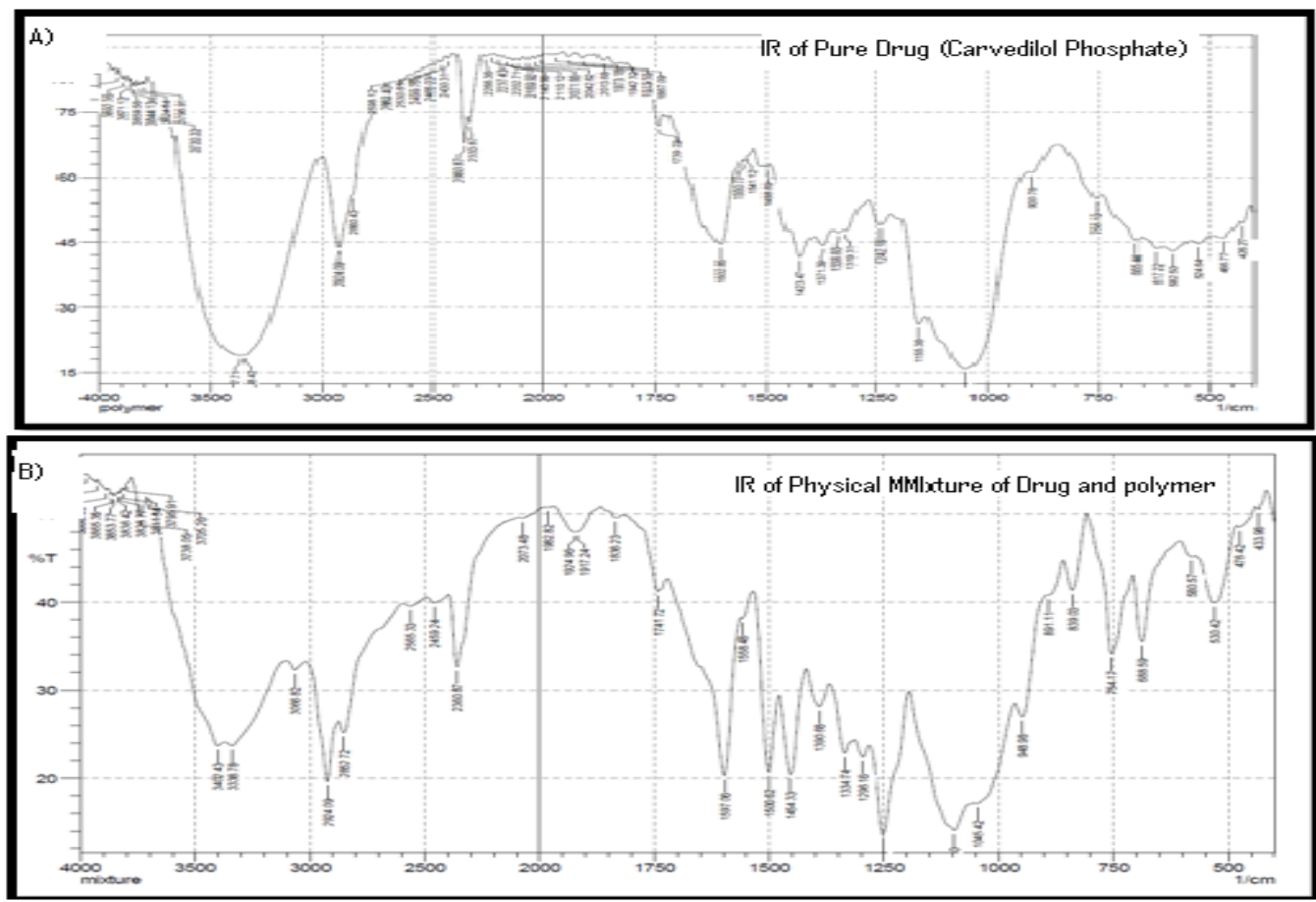

Figure 4: IR spectra A) Carvedilol Phosphate B) Physical Mixture of Drug and Polymer. 
Table 2: Precompression parameters of powder blend prepared for floating layer

\begin{tabular}{|c|c|c|c|c|c|c|c|c|c|c|}
\hline $\begin{array}{c}\text { Formulation } \\
\text { Code }\end{array}$ & \multicolumn{2}{|c|}{ Bulk Density (gm/cc) } & \multicolumn{2}{c|}{$\begin{array}{c}\text { Tap Density } \\
\text { (gm/cc) }\end{array}$} & \multicolumn{2}{c|}{ Hausner's Ratio } & \multicolumn{2}{c|}{$\begin{array}{c}\text { Compressibility } \\
\text { Index (\%) }\end{array}$} & \multicolumn{2}{c|}{$\begin{array}{c}\text { Angle of Repose } \\
\text { (Degrees) }\end{array}$} \\
\hline & Floating & Sustain & Floating & Sustain & Floating & Sustain & Floating & Sustain & Floating & Sustain \\
\hline F1 & 0.43 & 0.38 & 0.53 & 0.45 & 1.23 & 1.18 & 18.57 & 15.38 & 35.48 & 37.71 \\
\hline F2 & 0.42 & 0.38 & 0.55 & 0.44 & 1.31 & 1.15 & 23.61 & 12.82 & 40.43 & 41.29 \\
\hline F3 & 0.41 & 0.38 & 0.55 & 0.42 & 1.33 & 1.11 & 24.66 & 10.13 & 36.78 & 38.63 \\
\hline F4 & 0.40 & 0.38 & 0.56 & 0.46 & 1.39 & 1.23 & 28.00 & 18.75 & 38.67 & 31.78 \\
\hline F5 & 0.41 & 0.39 & 0.55 & 0.45 & 1.33 & 1.15 & 24.66 & 13.16 & 37.36 & 36.88 \\
\hline F6 & 0.41 & 0.39 & 0.56 & 0.46 & 1.37 & 1.18 & 27.03 & 15.58 & 36.71 & 39.63 \\
\hline F7 & 0.44 & 0.37 & 0.53 & 0.46 & 1.19 & 1.25 & 16.18 & 19.75 & 34.29 & 35.79 \\
\hline F8 & 0.44 & 0.38 & 0.54 & 0.47 & 1.21 & 1.22 & 17.65 & 17.95 & 31.70 & 35.22 \\
\hline F9 & 0.38 & 0.35 & 0.54 & 0.45 & 1.39 & 1.28 & 28.21 & 22.09 & 39.59 & 34.01 \\
\hline F10 & 0.39 & 0.38 & 0.53 & 0.45 & 1.33 & 1.18 & 25.00 & 15.19 & 38.25 & 34.49 \\
\hline F11 & 0.39 & 0.41 & 0.56 & 0.45 & 1.41 & 1.10 & 28.95 & 9.46 & 37.44 & 30.72 \\
\hline F12 & 0.43 & 0.39 & 0.52 & 0.45 & 1.21 & 1.15 & 17.14 & 13.16 & 34.73 & 35.46 \\
\hline F13 & 0.42 & 0.39 & 0.52 & 0.45 & 1.22 & 1.13 & 18.31 & 11.84 & 36.03 & 35.62 \\
\hline F14 & 0.41 & 0.38 & 0.54 & 0.45 & 1.30 & 1.18 & 23.29 & 15.38 & 37.88 & 37.54 \\
\hline F15 & 0.43 & 0.39 & 0.54 & 0.46 & 1.23 & 1.17 & 18.84 & 14.47 & 34.98 & 35.95 \\
\hline F16 & 0.38 & 0.38 & 0.55 & 0.45 & 1.42 & 1.16 & 29.49 & 14.10 & 41.64 & 37.54 \\
\hline
\end{tabular}

\section{Post compression parameters:}

In the evaluation of prepared tablet hardness was found to decrease with higher mucilage concentration it was in the range of 4.5 to $9.5 \mathrm{~kg} / \mathrm{cm}^{2}$. Whereas friability was within limits for all the formulations $(0.16 \%-0.47 \%)$. And other parameters like thickness, weight variation, and content uniformity were found to be in limits as per table 3 .
The Bioadhesive force or detachment stress was an important physicochemical parameter to measure as the used hydrophilic polymers are of bioadhesive nature. During study it was observed that as the concentration of bioadhesive polymers increased the bioadhesive force increased significantly. All formulations showed bioadhesive force in the range of $4 \times 10^{3}$ to $10 \times 10^{3}$ dynes $/ \mathrm{cm}^{2}$.

Table 3: Post compression parameters for bilayer tablets

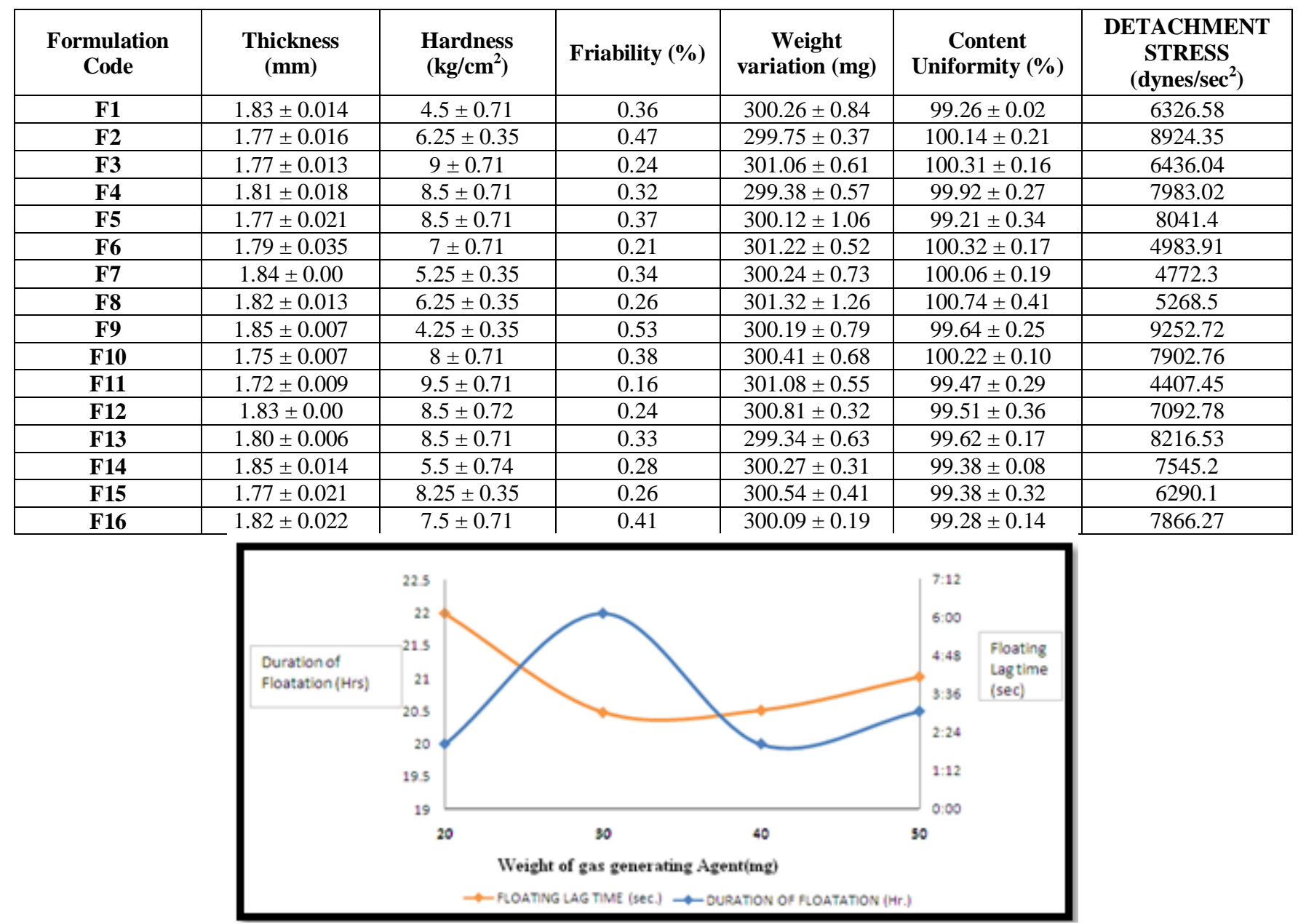

Figure 5: Comparison between floating lag time and floating duration.TIF 


\section{The floating lag time and the total floating time:}

The floating layer composition was selected based on the lag time and the buoyancy time of the floating layer. The optimum concentration of sodium bicarbonate incorporated in the floating layer was $30 \mathrm{mg}(\mathrm{F} 1)$, from figure (5). The sustained release layer was optimized based on its duration of floatation and In-vitro drug release pattern.

\section{Swelling Characteristics:}

The percent swelling or swelling index data were subjected to the Vergnaud model to determine the rate of swelling of the formulations. The generalized form of the Vergnaud model is as follows:

$$
\mathrm{M}_{\mathrm{t}}=\mathrm{k} \mathrm{t}^{\mathrm{n}}
$$

Where,

Mt - The amount of liquid transferred at time ( $\mathrm{t}$ ).

$\mathrm{k}$ - Swelling constant which depends on the amount of liquid transferred after infinite time, the porosity of matrix and diffusivity.

$\mathrm{n}$ - The exponent indicates the mechanism of water uptake.

By using swelling polymers and gas-generating agent, stable persistent floatation was obtained. As shown in the plot of resultant weight versus time in Figure (6), the bilayer tablets generated floating force of around 146.2 after $10 \mathrm{hrs}$ for formulation F7. The generated force was strong enough for the whole tablet to maintain on the surface of dissolution medium for as long as $20 \mathrm{hrs}$. All the formulations had the same composition in the floating layer, but different sustained release layer composition for each formulation might have brought the difference in the resultant weights for various formulations. The swelling index data fitted in the model with the value of exponent, $n$, in the range of $0.59-$ 0.79. (Table 4)

Table 4 Kinetic values for Vergnaud's equation

\begin{tabular}{|c|c|c|c|}
\hline $\begin{array}{c}\text { Formulation } \\
\text { code }\end{array}$ & $\begin{array}{c}\text { Kinetic } \\
\text { constant } \\
(\mathrm{k})\end{array}$ & $\begin{array}{c}\text { Swelling } \\
\text { exponent } \\
(\mathrm{n})\end{array}$ & $\begin{array}{c}\text { correlation } \\
\text { coefficient } \\
(\mathrm{r} 2)\end{array}$ \\
\hline F1 & 10.1833 & 0.7034 & 0.9845 \\
\hline F2 & 9.1975 & 0.6686 & 0.9823 \\
\hline F3 & 8.2022 & 0.6556 & 0.9943 \\
\hline F4 & 9.6675 & 0.6111 & 0.9801 \\
\hline F5 & 3.5381 & 0.787 & 0.928 \\
\hline F6 & 9.8399 & 0.6734 & 0.9812 \\
\hline F7 & 13.4439 & 0.6323 & 0.9918 \\
\hline F8 & 11.2838 & 0.5957 & 0.9946 \\
\hline F9 & 8.7263 & 0.6554 & 0.952 \\
\hline F10 & 7.9072 & 0.6705 & 0.9691 \\
\hline F11 & 5.6447 & 0.7297 & 0.9765 \\
\hline F12 & 11.3831 & 0.6415 & 0.9884 \\
\hline F13 & 10.3733 & 0.6189 & 0.9939 \\
\hline F14 & 11.3749 & 0.6239 & 0.9882 \\
\hline F15 & 10.0894 & 0.6457 & 0.9948 \\
\hline F16 & 7.49 & 0.6991 & 0.944 \\
\hline & & & \\
\hline
\end{tabular}

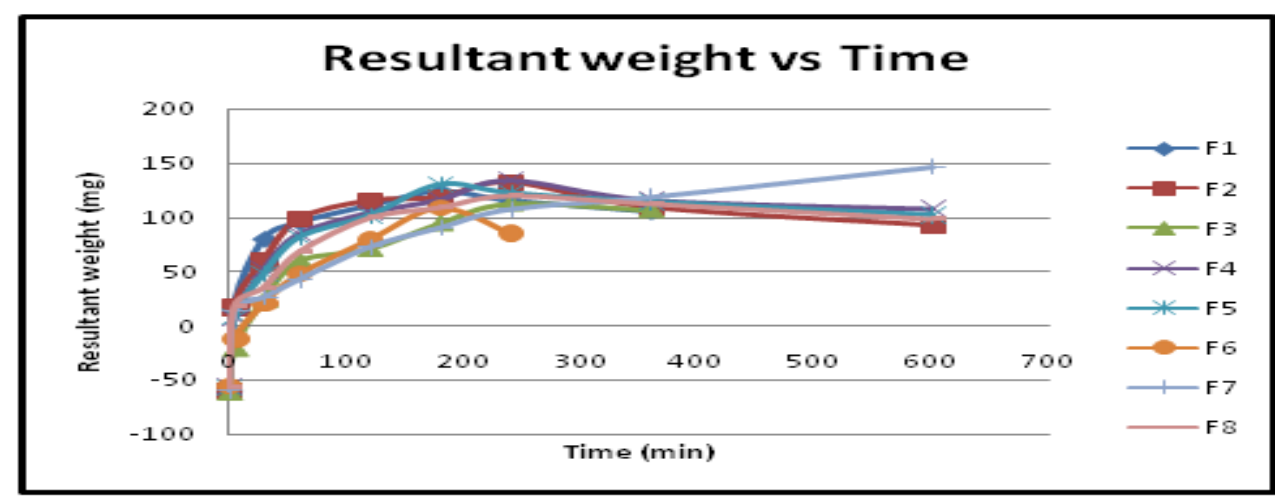

(a)

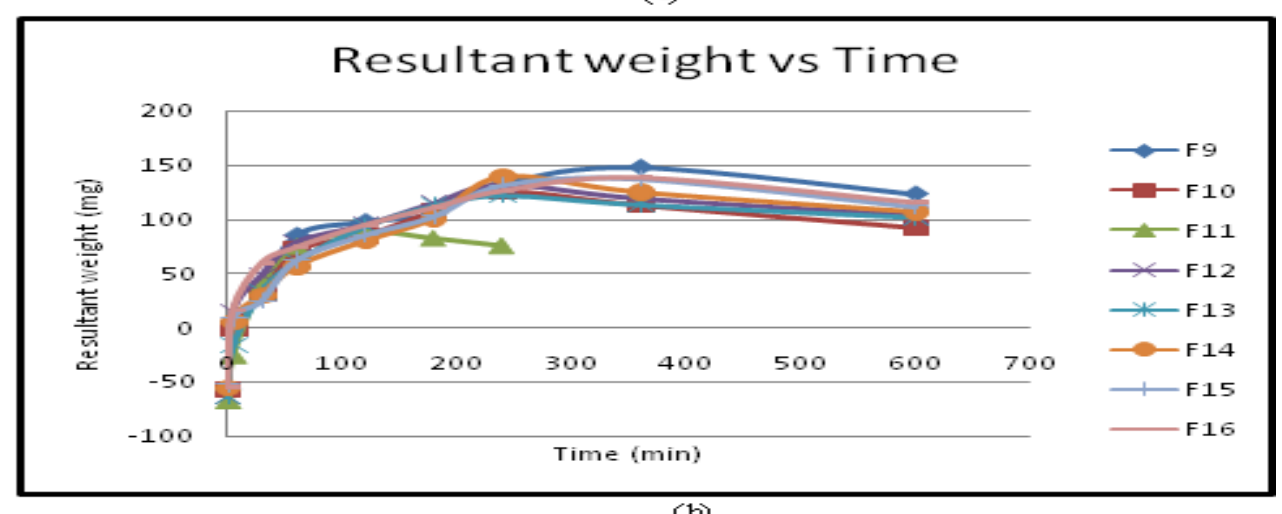

Figure 6: Graph of resultant weight vs. time for bilayer tablets 


\section{In-Vitro Drug release:}

In-vitro drug release was evaluated for all the formulations. The formulations were grouped depending on their duration of floatation into four groups i.e. those formulations had duration of floatation of around 22, 20, $18,14 \mathrm{hrs}$, then release was compared with each other and marketed extended release formulation drug release profile (figure 7).

- Group $1^{\text {st }}$ - Duration of floatation 22 hrs. - F2, F4, F7, F9, F15

- Group $2^{\text {nd }}-$ Duration of floatation 20hrs. - F13, F14, F16
- Group $3^{\text {rd }}$ - Duration of floatation 18hrs. - F3, F5, F8, F10, F12

- Group $4^{\text {th }}-$ Duration of floatation 14hrs. - F1, F6, F11

From the In-vitro drug release data kinetic values were determined and found the best suited model for drug release mechanism. Kinetic analysis of drug release table 5 shows that the formulation F1, F3, F6, F9, F10, F11, F14, F15 follows Higuchi model for drug release and formulation F2, F4, F5, F7, F8, F12, F13 follows Korsmeyer - Peppas model and drug released by non fickian mechanism as the value of $n$ is within limit of 0.45 -0.89 .

Table 5: Kinetic analysis of dissolution study

\begin{tabular}{|c|c|c|c|c|c|c|c|c|c|c|c|}
\hline \multirow{2}{*}{$\begin{array}{l}\text { FORMU- } \\
\text { LATION } \\
\text { CODE }\end{array}$} & \multirow[t]{2}{*}{$\%$ CDR } & \multicolumn{2}{|c|}{ ZERO ORDER } & \multicolumn{2}{|c|}{ FIRST ORDER } & \multicolumn{2}{|c|}{$\begin{array}{l}\text { KORSMEYER- } \\
\text { PEPPAS MODEL }\end{array}$} & \multicolumn{2}{|c|}{$\begin{array}{l}\text { HIGUCHI } \\
\text { MODEL }\end{array}$} & \multicolumn{2}{|c|}{$\begin{array}{l}\text { HIXSON- } \\
\text { CROWEL } \\
\text { MODEL }\end{array}$} \\
\hline & & K & $r^{2}$ & $\mathrm{~K}$ & $r^{2}$ & $\mathrm{n}$ & $r^{2}$ & K & $r^{2}$ & K & $r^{2}$ \\
\hline F1 & $98.19 \pm 0.61$ & 0.10 & 0.9374 & 0.002 & 0.60 & 0.67 & 0.9767 & 3.27 & 0.9921 & 0.004 & 0.9606 \\
\hline F2 & $71.66 \pm 0.99$ & 0.05 & 0.9747 & 0.001 & 0.65 & 0.58 & 0.9971 & 1.91 & 0.9820 & -0.001 & 0.9907 \\
\hline F3 & $84.94 \pm 0.98$ & 0.07 & 0.9451 & 0.001 & 0.66 & 0.63 & 0.9863 & 2.50 & 0.9868 & -0.002 & 0.9815 \\
\hline F4 & $93.80 \pm 0.38$ & 0.06 & 0.9415 & 0.001 & 0.59 & 0.57 & 0.9935 & 2.36 & 0.9931 & -0.002 & 0.9693 \\
\hline F5 & $84.32 \pm 0.42$ & 0.07 & 0.9792 & 0.001 & 0.67 & 0.63 & 0.9978 & 2.48 & 0.9790 & -0.002 & 0.9795 \\
\hline F6 & $95.70 \pm 0.20$ & 0.10 & 0.9311 & 0.002 & 0.63 & 0.67 & 0.9866 & 3.26 & 0.9953 & -0.003 & 0.9766 \\
\hline F7 & $74.69 \pm 0.52$ & 0.05 & 0.8204 & 0.001 & 0.53 & 0.61 & 0.9880 & 2.10 & 0.9563 & -0.001 & 0.8846 \\
\hline F8 & $79.54 \pm 0.20$ & 0.06 & 0.8707 & 0.001 & 0.56 & 0.62 & 0.9848 & 2.36 & 0.9795 & -0.002 & 0.9396 \\
\hline F9 & $63.68 \pm 0.36$ & 0.04 & 0.9382 & 0.001 & 0.52 & 0.72 & 0.9823 & 1.70 & 0.9992 & -0.001 & 0.9733 \\
\hline F10 & $82.23 \pm 0.35$ & 0.06 & 0.9370 & 0.001 & 0.55 & 0.70 & 0.9860 & 2.42 & 0.9954 & -0.002 & 0.9860 \\
\hline F11 & $98.68 \pm 0.29$ & 0.12 & 0.9095 & 0.002 & 0.58 & 0.85 & 0.9682 & 3.72 & 0.9846 & -0.005 & 0.9374 \\
\hline F12 & $76.85 \pm 1.13$ & 0.06 & 0.9515 & 0.001 & 0.64 & 0.61 & 0.9983 & 2.23 & 0.9960 & -0.001 & 0.9883 \\
\hline F13 & $71.05 \pm 0.26$ & 0.05 & 0.9724 & 0.002 & 0.57 & 0.69 & 0.9935 & 2.14 & 0.9803 & -0.001 & 0.9926 \\
\hline F14 & $80.91 \pm 1.48$ & 0.06 & 0.9111 & 0.002 & 0.40 & 1.22 & 0.9282 & 2.33 & 0.9907 & -0.001 & 0.9709 \\
\hline F15 & $87.82 \pm 0.99$ & 0.06 & 0.9283 & 0.001 & 0.43 & 1.04 & 0.9422 & 2.36 & 0.9971 & -0.002 & 0.9851 \\
\hline F16 & $67.53 \pm 0.39$ & 0.05 & 0.9302 & 0.001 & 0.64 & 0.60 & 0.9936 & 1.97 & 0.9933 & -0.001 & 0.9689 \\
\hline
\end{tabular}

Only the prepared formulations which shown floating ability for more than $20 \mathrm{hrs}$ was considered as suitable formulations. So, drug release profiles of these formulations were compared with the marketed extended release formulation drug release profile table 6 . From all the formulations F4 shown the highest similarity factor 66.14 , lowest difference factor 6.58 , and least value for Rascigno index $(\xi 1=0.0328, \xi 2=0.0349)$ which revealed F4 was the optimised formulation which satisfies all the requirements.

Table 6: Parameters for release profile comparison

\begin{tabular}{|c|c|c|c|c|}
\hline \multirow{2}{*}{$\begin{array}{c}\text { FORMULATION } \\
\text { CODE }\end{array}$} & $\begin{array}{c}\text { f'1 } \\
\text { VALUE }\end{array}$ & $\begin{array}{c}\text { f2 } \\
\text { VALUE }\end{array}$ & \multicolumn{2}{|c|}{$\begin{array}{c}\text { RASCIGNO } \\
\text { INDEX }\end{array}$} \\
\cline { 2 - 5 } & & & $\mathbf{( \xi 1 )} \mathbf{i}=\mathbf{1}$ & $\mathbf{( \xi 2 )} \mathbf{i}=\mathbf{2}$ \\
\hline F2 & 35.68 & 35.17 & 0.1784 & 0.1688 \\
\hline F4 & $\mathbf{6 . 5 8}$ & $\mathbf{6 6 . 1 4}$ & $\mathbf{0 . 0 3 2 8}$ & $\mathbf{0 . 0 3 4 9}$ \\
\hline F7 & 15.01 & 46.64 & 0.0751 & 0.0904 \\
\hline F9 & 38.56 & 32.77 & 0.1927 & 0.1926 \\
\hline F15 & 7.2 & 63.49 & 0.036 & 0.0436 \\
\hline
\end{tabular}




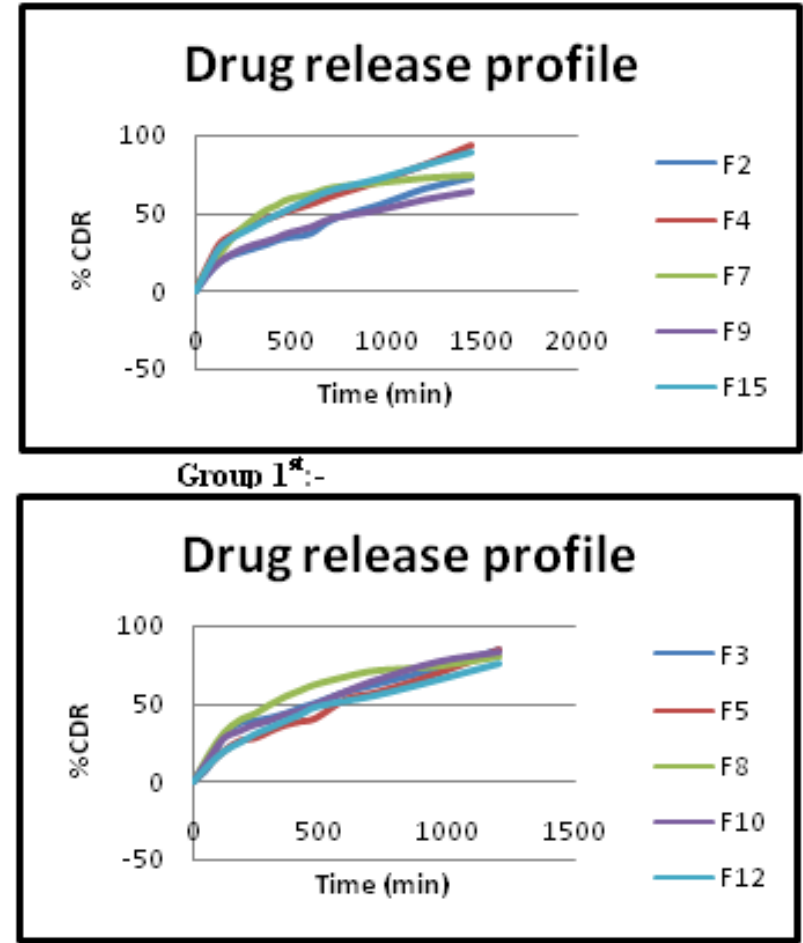

Group $3^{\text {T1 }}$
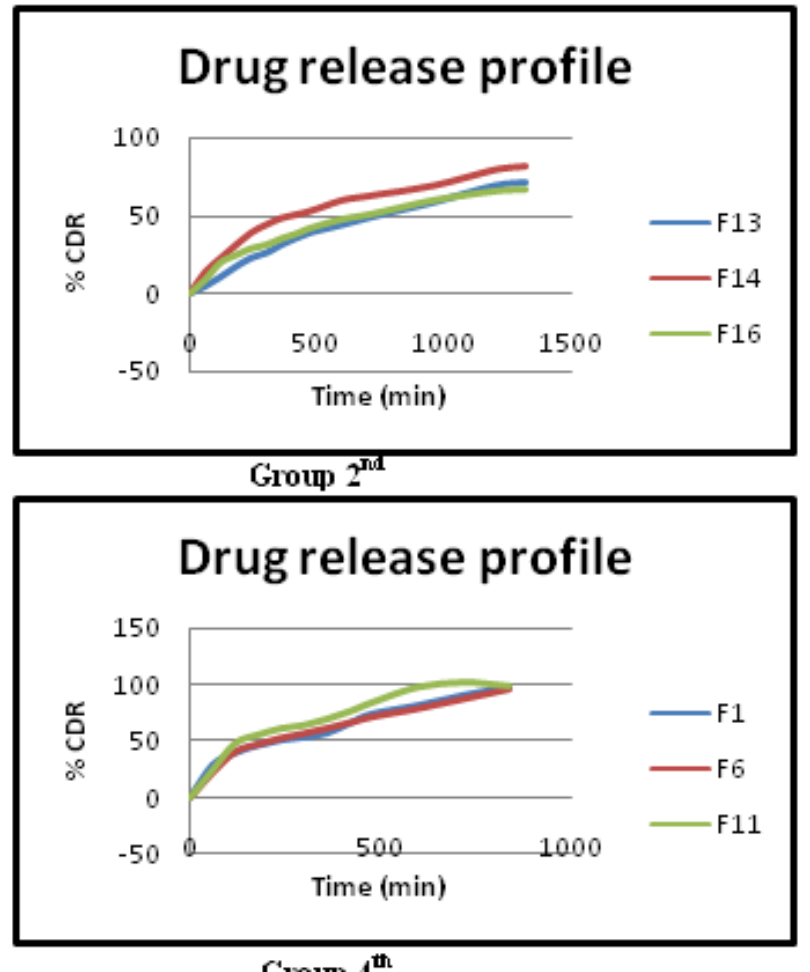

Group $4^{\text {th }}$

Figure 7: Graph showing drug release profile of bilayer tablet formulations

\section{DISCUSSION:}

Our aim was to use natural polymers in formulation to minimize the proportion of synthetic polymers and to study the effect of polymer and Mucilage concentrations on floating duration and drug release.

For this first primary evaluations were done for mucilage. As per Farhoosh R. et al. ${ }^{21}$ at low shear rate, mucilage molecules are disarranged and only partially aligned, resulting in a high viscosity and with increase shear rate, the molecules become oriented and aligned, thus resulting in a decrease in inner friction and lower viscosity. It was also found that with increasing concentration of mucilage solution there was increase in viscosity of OBM. According to Vardhanabhuti et.al. ${ }^{22}$ linear and stiff molecules have a large hydrodynamic size, which contributes to high viscosity and pseudoplasticity in mucilage solution. This could be due to the polar hydroxyl groups in the mucilage and hence their extent of hydrodynamic interaction.

The higher value of WAC at neutral $\mathrm{pH}$ may be related to molecular chains which remain in a close to the rod conformation in the solution. In more alkaline regions it may possible that alkaline depolymerization reactions show lower WAC. And in lower $\mathrm{pH}$ charge suppression results in a smaller conformation of the polymer chains because of acidic components exist in the free acid form which may result in lower WAC compared to neutral conditions. As the water absorption capacity and Viscosity was very high the mucilage is a good candidate for the floating and sustaining drug release.

Firstly the experiment was performed with simple OBM, but the problems occurred as early disintegration of tablets in 2-3 hrs, more friable tablets due to poor matrix forming ability, poor flow property, non uniform mixing with powder blend because of low density and non uniform appearance of tablets. From morphological study it is clear that the surface properties were improved after Spray dying than that of simple form.

Floating layer was separately prepared to avoid any interference of the alkaline sodium carbonate in the release of drug. HPMC - K $100 \mathrm{M}$ showed better floating capabilities due to greater molecular weight and has the fastest rate of hydration due to the hydrophobic and hydrophilic substituents i.e. methoxyl group and hydroxypropyl group on it. OBM was used as filler, binder due to its ability to swell and gel. When used with HPMC and Sodium bicarbonate due to high viscosity of the mucilage and HPMC, $\mathrm{CO}_{2}$ gas is entrapped within the swollen structure and increases the buoyancy of the formulation and also helped to decrease the lag time.

In order to get shorter lag time increasing concentration of effervescent mixture was used, and it was observed that at higher concentration floating layer dispersed where as at lower concentration of $20 \mathrm{mg}$ lag time was prolonged.

The second layer (sustained release layer) provided control release of active material and contains drug, HPMC K100 $\mathrm{M}$ as a hydrophilic matrix material. OBM was used as release retardant due to its swelling, gelling ability and MCC was added as diluent. An attempt was made to reduce the concentration of HPMC's which is costlier, by combining them with OBM to achieve the desired sustained release pattern.

A value of $\leq 0.5$ for $n$ in the swelling index data indicates a diffusion-controlled mechanism in which the rate of diffusion of the liquid is much less as compared with the rate of relaxation of the polymer segment. A value of one 


\section{Shilpa et al}

Journal of Drug Delivery \& Therapeutics; 2012, 2(5), 9-19

for $n(n=1)$ suggests that the stress relaxation process is very slow as compared with the rate of diffusion. This means that the liquid diffuse through the polymer matrix at a constant velocity showing an advancing front marking the limit of liquid penetration. Behind this front is swollen gel and ahead of it is the polymer in the glassy state. A value of $n$ between 0.45 and 1 indicates an anomalous or complex behaviour in which the rate of diffusion of the liquid and that of relaxation are of the same magnitude. According to this the matrices having $\mathrm{n}$ value between $0.59-0.79$ follows diffusion and stress relaxation mechanism, and shows anomalous or complex behaviour, the liquid diffuses through the polymer matrix at a constant velocity, and the rate of diffusion of the liquid and that of stress relaxation of the polymer are almost of the same magnitude. ${ }^{6}$ The resultant weight force is responsible for floating and depends upon the the weight and the floating forces. As the water gets absorbed into the matrix, weight of matrix increases and compensated by swelling in order to keep the dosage form in floating state.

The dissolution kinetics showed results similar to that obtained from of Vergnaud model, the non-fickian drug release from the tablet dissolution data, which confirmed the mechanism of drug release. Also the similarity factor is

\section{REFERENCES:}

1. Sweetman SC, Martindale, The complete drug reference, Pharmaceutical Press, London, Chicago, 34th edition 2005: 881.

2. Desai S, Bolton S. Floating controlled-release drug delivery systems: in vitro-in vivo evaluation. Pharm Res. 1993; 10: 13211325.

3. Chueh HR, Zia H, Rhodes CT. Optimization of Sotalol floating and bioadhesive extended release tablet formulations. Drug Development and Industrial Pharmacy. 1995; 2: 1725-1747.

4. Chavan M, Jain P, Chaudhari S, Shear R, Vavia P. Development of sustained release gastroretentive drug delivery system for Ofloxacin: In vitro and in vivo evaluation. International Journal of Pharmaceutics. 2005; 304: 178-184.

5. Liandong H, Li L, Xun Y, Wei L. Floating matrix dosage form for Dextromethorphan hydrobromide based on gas forming technique: In vitro and in vivo evaluation in healthy volunteers. European Journal of Pharmaceutical Science 2011; 42: 99-105.

6. Chaudhari P, Chaudhari S, Barhate N. Design and Evaluation of Bilayer Floating Tablets of Tizanidine Hydrochloride. Indian Journal of Pharmaceutical Education and Research. 2008; 42(1): 36-47.

7. Whitehead L, Fell JT, Collett JH. Amoxycillin release from a floating dosage form based on alginates. International Journal of Pharmaceutics. 2000; 210: 45-49.

8. Rouge N, Allemann E, Gex-Fabry M, Balant L, Cole ET, Buri P, Doelker E. Comparative pharmacokinetic study of a floating multiple-unit capsule, a high density multiple-unit capsule and an immediate-release tablet containing $25 \mathrm{mg}$ Atenolol. Pharmaceutica Acta Helvetiae. 1998; 73: 81-87.

9. Santus G, Lazzarini G, Bottoni G. An in vitro-in vivo investigation of oral bioadhesive controlled release Furesomide formulations. European Journal of Pharmaceutics and Biopharmaceutics. 1997; 44: 39-52.

10. Dolas RT., Hosmani A, Bhandari A. Novel Sustained Release Gastroretentive Drug Delivery System: A Review. International Journal of Pharma Research and Development. 2011; 2(11): 2641.

11. Deshpande AA, Rhodes CT, Shah NH, Malick AW. Controlledrelease drug delivery systems for prolonged gastric residence: an overview. Drug Development and Industrial Pharmacy. 1996; 22: 531-539. a logarithmic reciprocal square root transformation of the sum of squared

error and is a measurement of the similarity in the percent dissolution between the two curves ${ }^{23}$. This model independent method is most suitable for dissolution profile comparison between marketed and optimized formulation, therefore values showing highest similarity factor, least difference factor indicate the formulation to be the best formulation.

\section{CONCLUSION:}

From the results it was concluded that the prepared floating bilayer matrix tablet would be the better choice for Carvedilol phosphate than other conventional sustained release dosage forms as it provides drug in a soluble form to its site of absorption for $24 \mathrm{hrs}$ which may result in increase of bioavailability of drug. At the same time the natural polymers such as spray dried OBM has proved to have a great potential for usage in the gastroretentive dosage forms as a swelling and Sustaining polymer, and when used in combination with synthetic polymers shows good matrix forming properties with better control on release rate of drug from matrix.

12. Sriamornsak P, Thirawong N, Korkerd K. Swelling, erosion and release behaviour of alginate-based matrix tablets. European Journal of Pharmaceutics and Biopharmaceutics. 2007; 66: 435450 .

13. Gutierrez Sanchez PE, Hernandez-León A, Villafuerte-Robles L. Effect of sodium bicarbonate on the properties of Metronidazole floating tablets made of Methocel K4M and Carbopol 971P NF. Drug Development and Industrial Pharmacy. 2008; 34: 171-180.

14. Hoffman A, Stepensky D. Pharmacodynamic aspects of modes of drug administration for optimization of drug therapy. Critical Review of Therapeutic Drug Carrier System. 1999; 16: 571-639.

15. Hwang SJ, Park H, Park K. Gastric retentive drug-delivery systems. Critical Review of Therapeutic Drug Carrier System. 1998; 15: 243-284.

16. Razavi SMA, Karazhiyan H. Flow properties and thixotropy of selected hydrocolloids: experimental and modeling studies. Food Hydrocolloids. 2009; 23: 908-912.

17. Sciarini LS, Maldonado F, Ribotta PD, Perez GT et al. Chemical composition and functional properties of Gleditsia triacanthos gum. Food Hydrocolloids, 2009; 23: 306-313.

18. Seham SAE, Nahed DM, Gehanne ASA. Development of in situ gelling and mucoadhesive Mebeverine Hydrochloride solution for rectal administration. Saudi Pharmaceutical Journal. 2003; 11(4): 159-77.

19. Saravanan D, Gomathi et al. Comparative Study of Thermal Stability Using Natural Polymer Blend by Cross Linking. Scholars research library. 2011; 3 (6): 342-350.

20. Mucha M, Pawlak A. Thermal analysis of Chitosan and its blends. Thermochim Acta. 2005; 427: 69-76.

21. Farhoosh R, Riazi A. A compositional study on two current types of salep in Iran and their rheological properties as a function of concentration and temperature. Food Hydrocolloids. 2007; 21: 660-666.

22. Vardhanabhuti B, Ikeda S. Isolation and characterization of hydrocolloids from monoi (Cissampelos Pareira) leaves. Food Hydrocolloids. 2006; 20: 885-891.

23. Dash S, Murthy PN, Nath L, Chowdhury P. Kinetic modeling on drug release from controlled drug delivery systems. Acta Poloniae Pharmaceutica - Drug Research, 2010; 67 (3): 217-223. 